\title{
The Potential of Prospective Teachers Experiencing Differentiated Instruction in a Mathematics Course
}

\author{
Michelle T. Chamberlin \\ University of Wyoming
}

\begin{abstract}
Differentiated instruction is a promising approach for supporting the diverse needs of students. To support prospective teachers with the challenge of implementing differentiated instruction in their future instruction and to meet their diverse needs as college students, we decided to incorporate differentiated instruction in our mathematics content course for them. The specific objective of this study was then to examine how the prospective elementary teachers experienced differentiated instruction in the mathematics content course, whether it met their varying instructional needs, and how it may impact their future mathematics teaching. Qualitative and quantitative analyses revealed that the prospective teachers found the differentiated instruction supportive of their diverse needs and that they plan to incorporate similar features in their future instruction. However, the prospective teachers' comments did reveal additional aspects about differentiated instruction to learn and strengthen. Suggestions for revising the mathematics content course and enhancing the differentiated instruction are provided along with directions for further research.
\end{abstract}

Keywords: Differentiated instruction, mathematics courses, prospective teachers, elementary grades

In contemporary classrooms worldwide, students have many diverse instructional needs, including different abilities, interests, learning styles, and cultural backgrounds. Indeed, "educators no longer have a legitimate choice about whether to respond to the academically diverse populations in most classrooms; rather, they can only decide how to respond" (Tomlinson et al., 2003, p. 121). One way grade kindergarten-12 teachers have addressed these needs is through differentiated instruction, which is supported by literature on learning and has improved students' learning. Yet, differentiated instruction is rarely utilized at the undergraduate level, despite the diverse instructional needs of college students. Furthermore, most teachers, including prospective teachers, struggle with addressing learner variance in the classroom. For these two reasons, we decided to incorporate differentiated instruction in our offering of an undergraduate mathematics course for prospective elementary teachers. The objective of this study was to examine how these prospective elementary teachers experienced the differentiated instruction and how it may impact their future mathematics teaching. We found the differentiated instruction to meet the diverse instructional needs of our prospective teachers, as reported from their perspective. In addition, the prospective teachers enhanced their plans to incorporate differentiated instruction in their future mathematics instruction, while some learning still remained.

\section{Relevant Literature}

Differentiated instruction is a process of proactively modifying teaching methods, learning activities, and assessments to meet the diverse needs of students and thereby 
maximize learning (Subban, 2006; Tomlinson, 1999). These changes are based on students' readiness (current understandings), personal interests, and learning profiles (learning styles, culture, and gender) (Tomlinson et al., 2003). Differentiated instruction is supported by theoretical literature on learning as well as empirical research. Differentiating according to student readiness, interests, or learning profile has been linked with benefits for achievement, study habits, social interaction, cooperation, attitudes toward school and learning, self-worth, motivation, persistence, creativity, and engagement (Subban, 2006; Tomlinson et al., 2003; Tomlinson \& McTighe, 2006). Empirical studies have found that differentiated instruction leads to achievement gains on standardized tests, including mathematics (Hodge, 1997). While gains have been found for all racial and socioeconomic groups (Brighton, Hertberg, Moon, Tomlinson, \& Callahan, 2005; Tomlinson, 2005), some studies have found particular improvement for students historically low performing, with exceptional needs, and with gifted abilities (Batts \& Lewis, 2005; Brimijoin, 2002; McAdamis, 2001).

Several principles guide differentiated instruction (Tomlinson, 1999; Tomlinson \& Eidson, 2003). Assessment is ongoing, informs instruction, and includes the assessment of students' understanding of the material, their personal interests, and their learning profiles. As such, teachers have to articulate what is essential for students to learn about a subject. Teachers attend to student differences, accepting students as they are but expecting them to become and understand all that they can. All students participate in respectful work at a level attainable for them, completing activities that emphasize critical thinking and individual growth. The teacher and the students collaborate in learning, maintaining a balance between teacher-assigned and student-selected tasks and working arrangements. Teachers are purposeful and flexible in their use of groups, whole class discussion, time, materials, and classroom space. Planning is proactive; the teacher designs lessons that address learner variance from the outset rather than relying on adjustments during real-time. Finally, teachers differentiate their instruction with regard to content, learning process, or learning product.

We decided to incorporate differentiated instruction in our mathematics content course for prospective teachers for two reasons: (a) to possibly address the diverse needs of these college students, and (b) to potentially assist them with implementing differentiated instruction in their future mathematics teaching. Just as with grade kindergarten-12 students, college students are diverse with regard to their backgrounds and instructional needs. They too differ by academic preparation, interests, age, learning styles, and cultural backgrounds. In 2003-2004, the National Center for Educational Statistics [NCES] found that 36\% of undergraduates reported taking a remedial course (Horn \& Nevill, 2006). With respect to mathematics, the Business-Higher Education Forum (2005) reported that $22 \%$ of all college freshmen fail to meet performance levels for entry-level mathematics courses, and according to ACT results, only $40 \%$ of incoming freshmen are ready to take college algebra (Cavanagh, 2004). Students also vary in several dimensions impacting their learning profile. According to the NCES (Horn \& Nevill, 2006), in 2003-04 the average age of undergraduates was 26 with $47 \%$ of undergraduates aged $19-23$ years, $17 \%$ aged $24-29$ years, $14 \%$ aged $30-39$ years, and $12 \%$ aged 40 years or older. Fifty-eight percent of these undergraduates were women, and $63 \%$ were white, $14 \%$ black, $13 \%$ Hispanic, and 5\% Asian. Eleven percent of undergraduates reported having a disability (Horn \& Nevill, 2006). 
Unfortunately, such differences do not appear to be addressed through instruction in college mathematics classes. College students often report their mathematics classes to be impersonal, irrelevant to their interests, and intellectually unstimulating. For example, Anthony (2000) identified factors that influence students' success in first-year mathematics courses and found that students wanted a more personal approach in their classes. Factors contributing to students' failure or displeasure resulted from boring presentations of content along with a perceived lack of content relevance. In a synthesis on why some students stay enrolled in quantitative gatekeeper courses while others with comparable ability and interest decide not to do so, Gainen (1995) reported, "Many students learn best in a context that invites personal connection to professors, peers, and the subject matter. For these students, the impersonal, competitive culture often found in gatekeeper courses conflicts with their values and expectations" (p. 11). Furthermore, such classes were often unstimulating, not just for students that may struggle but for many well-qualified students as well (Gainen, 1995; Treisman, 1992). Similar concerns were reported outside the United States. Specifically, Willis (1993) found that content relevance and degree of interest were important to a number of first and second year students in fostering their involvement in a course.

College students also frequently report their mathematics classes to rely solely on lecture and to emphasize rote rather than active learning. For example, in a multi-institution study of 335 students who persisted in or left science, mathematics, or engineering majors, $75 \%$ of all interviewees and $89 \%$ of those who switched complained of "poor teaching" (Seymour, 1992). Factors of poor teaching included lecturing with an emphasis on rote learning, failing to offer intellectual stimulation, dull material and presentation, lack of enthusiasm for the subject, and unapproachable demeanor. Despite these shortcomings and the need to address college students' diverse instructional needs, differentiated instruction is scarcely used at the undergraduate level, especially in mathematics classes for which no such instances were found in the education literature. Thus, one intent of this study was to examine differentiated instruction as a means for addressing such concerns.

We also decided to incorporate differentiated instruction in the hopes of encouraging the prospective teachers to do so in their future mathematics teaching. Despite the potential of differentiated instruction, most teachers do not address learner differences, instead planning for whole-class instruction (Tomlinson et al., 2003). When teachers do attempt to differentiate, their efforts are often not effective, using only minor improvisations or reactive steps. Such dilemmas are heightened with prospective teachers (Tomlinson et al., 1994). First, while prospective teachers believe in student differences, they feel it is nearly impossible to address such needs (Wertheim \& Leyser, 2002). Second, prospective teachers are often weak in using effective assessment techniques. Third, prospective teachers are not proactive in differentiating; rather, they tend to use a one-size-fits-all approach and only differentiate reactively. Fourth, prospective teachers have a limited repertoire of strategies for enacting differentiation. For many teachers, the most frequently used pedagogical strategy is a limited use of heterogeneous groups whereby 'advanced' students tutor 'struggling' students. Finally, prospective teachers report several factors, which discourage them from addressing student differences, including management concerns, a traditional view of the teacher as the dispenser of knowledge, and a perceived absence of support from cooperating teachers, university supervisors, and teacher education programs. 
An emerging suggestion is to support teachers with learning about differentiation in their teacher preparation programs (Gould, 2004; Tomlinson et al., 1994; Wertheim \& Leyser, 2002). Gould recommends prospective teachers experience differentiated instruction in their college courses, study examples of differentiated lessons, be placed in differentiated classrooms, and reflect on their own efforts to differentiate instruction. In particular, within college courses, professors should model differentiated instruction and explain their differentiation efforts to prospective teachers. However, very few teacher education programs have reported on differentiated coursework; in a literature review, only two instances of differentiating college coursework for prospective teachers were found. Huss-Keeler and Brown (2007) used differentiated instruction to meet the diverse needs of graduate initial certification and graduate certified teachers in two cross-listed early childhood mathematics classes. They found that differentiated instruction allowed the diverse candidates to benefit from the class. However, the authors did not examine how the differentiated course impacted the teachers' future instructional plans. Sands and Barker (2004) differentiated a lesson in their course entitled Integrated Curriculum Workshops I and II. Anecdotal information from the prospective teachers revealed that the differentiation allowed them to work at their own levels of knowledge and that the teaching was authentic to the premise of differentiated instruction by being differentiated. Examining the impact of the differentiated lesson was beyond the scope of the study, but the authors do state, "In the future, conducting research that reveals whether these efforts lead to data indicating teacher candidates' learning and ability to implement the practices targeted would be the logical next step in this line of inquiry" (p. 46).

Thus, to investigate the potential of differentiated instruction for meeting the diverse needs of students in undergraduate mathematics courses and to support prospective teachers in learning about differentiation, we differentiated our mathematics content course for prospective elementary teachers. With regard to an impact on the prospective teachers' mathematical learning, we found positive effects as a result of the differentiated instruction (Chamberlin \& Powers, 2010). However, we also wanted to learn about the prospective teachers' interpretations of the differentiated instruction (whether it addressed their diverse needs) and about potential impacts on their future mathematics instruction. As such, the current study addressed the following research questions: When prospective elementary teachers experience differentiated instruction in a mathematics content course, how do they describe their experience, including affordances and constraints for their learning? How do they perceive the experience will impact their future mathematics teaching?

\section{Methods}

The mathematics course was a three-credit number and operations course for prospective elementary teachers. Three instructors, including the author, taught five sections in fall 2008 at two mid-sized universities in the Rocky Mountain region of the United States (see Table 1). All five sections were similar in scope with material presented in a problem solving and exploratory context. Content covered the real number system in conjunction with the four arithmetic operations. Following informed consent procedures, 108 students voluntarily 
participated in the study; see Table 2 for information about students' diverse backgrounds and experiences.

Table 1

Information about the instructors for the sections.

\begin{tabular}{cccccc}
\hline Pseudonym & Sections & Gender & Course Experience & Current Position & Highest Degree \\
\hline Chelsea & 2 & Female & 1 & Graduate student & M.S. Applied Math \\
Author & 1 & Female & 5 & Asst. Professor & Ph.D. Math Education \\
Mark & 2 & Male & 0 & Graduate student & M.S. Math \\
\hline
\end{tabular}

Table 2

Demographic information about the student participants.

\begin{tabular}{|c|c|c|c|}
\hline Factor & Categories & Frequency & Percentage \\
\hline \multirow[t]{5}{*}{ Age } & 18 years & 43 & $40 \%$ \\
\hline & 19 years & 36 & $33 \%$ \\
\hline & 20 years & 15 & $14 \%$ \\
\hline & $21+$ years & 12 & $12 \%$ \\
\hline & Not reported & 2 & $2 \%$ \\
\hline \multirow[t]{3}{*}{ Gender } & Female & 96 & $89 \%$ \\
\hline & Male & 10 & $9 \%$ \\
\hline & Not reported & 2 & $2 \%$ \\
\hline \multirow[t]{6}{*}{ Year } & Freshman & 67 & $62 \%$ \\
\hline & Sophomore & 24 & $22 \%$ \\
\hline & Junior & 10 & $9 \%$ \\
\hline & Senior & 3 & $3 \%$ \\
\hline & Other & 1 & $1 \%$ \\
\hline & Not reported & 2 & $2 \%$ \\
\hline \multirow[t]{5}{*}{ Ethnicity } & White/Caucasian & 82 & $76 \%$ \\
\hline & Hispanic/Latino/Mexican & 10 & $9 \%$ \\
\hline & Asian & 2 & $2 \%$ \\
\hline & Other & 2 & $2 \%$ \\
\hline & Not reported & 12 & $11 \%$ \\
\hline \multirow[t]{5}{*}{ Major } & Elementary Education & 76 & $70 \%$ \\
\hline & Early Childhood & 11 & $10 \%$ \\
\hline & Special Education & 14 & $13 \%$ \\
\hline & Other & 6 & $6 \%$ \\
\hline & Not reported & 2 & $2 \%$ \\
\hline
\end{tabular}

The course included four units, each of 10-12 50-minute class periods: Meaning of Numbers, Operations with Whole Numbers and Integers, Operations with Rational Numbers, and Number Theory. Within each unit, we differentiated instruction multiple times based on students' readiness, interests, and learning profiles (see Chamberlin \& Powers (2010) for further information). Table 3 provides an overview of the Meaning of Numbers unit while the 
following paragraphs provide specific examples of how the instruction was differentiated with regard to students' readiness, interests, and learning profiles.

Table 3

Overview of meaning of numbers unit ${ }^{1}$

\begin{tabular}{|c|c|c|c|c|}
\hline Class & Topic & $\begin{array}{l}\text { Group } \\
\text { Formation }\end{array}$ & Activities & Assignments \\
\hline 1 & $\begin{array}{l}\text { Numeration } \\
\text { systems }\end{array}$ & Random & $\begin{array}{l}\text { Investigation of Egyptian and } \\
\text { Babylonian systems through an on-line } \\
\text { applet }\end{array}$ & $\begin{array}{l}\text { Formative } \\
\text { assessment } \\
\text { on } \\
\text { numeration } \\
\text { systems }\end{array}$ \\
\hline 2 & $\begin{array}{l}\text { Numeration } \\
\text { systems } \\
\text { continued }\end{array}$ & $\begin{array}{l}\text { By formative } \\
\text { assessment }\end{array}$ & $\begin{array}{l}\text { According to readiness - Explore base } \\
\text { three or more work with Egyptian and } \\
\text { Babylonian }\end{array}$ & $\begin{array}{l}\text { Writing } \\
\text { assignment } \\
\text { on } \\
\text { numeration } \\
\text { systems }\end{array}$ \\
\hline 3 & $\begin{array}{l}\text { Sets of } \\
\text { numbers }\end{array}$ & Student choice & $\begin{array}{l}\text { Number Sort - sorting numbers to elicit } \\
\text { different sets }\end{array}$ & Quiz \\
\hline 4 & $\begin{array}{l}\text { Whole } \\
\text { numbers and } \\
\text { integers }\end{array}$ & $\begin{array}{l}\text { By personal } \\
\text { interests }\end{array}$ & $\begin{array}{l}\text { Base Ten Riddles (representing whole } \\
\text { numbers with base ten blocks) and then } \\
\text { Counter Game (representing integers } \\
\text { with two-color counters) }\end{array}$ & Homework \\
\hline 5 & Fractions & Random & $\begin{array}{l}\text { Sharing Tasks to elicit fractions and then } \\
\text { representing fractions with } \\
\text { manipulatives }\end{array}$ & $\begin{array}{l}\text { Formative } \\
\text { assessment } \\
\text { on fractions } \\
\text { and quiz }\end{array}$ \\
\hline 6 & $\begin{array}{l}\text { Mixed } \\
\text { numbers and } \\
\text { the unit whole }\end{array}$ & $\begin{array}{l}\text { By formative } \\
\text { assessment }\end{array}$ & $\begin{array}{l}\text { Video of child converting an improper } \\
\text { fraction and then according to readiness } \\
\text { - more work on representing fractions or } \\
\text { unit whole }\end{array}$ & Homework \\
\hline 7 & $\begin{array}{l}\text { Comparing } \\
\text { fractions }\end{array}$ & Random & $\begin{array}{l}\text { Mentally ordering several fractions on a } \\
\text { number line and then generating rules } \\
\text { for ordering fractions by size }\end{array}$ & Quiz \\
\hline 8 & $\begin{array}{l}\text { Representing } \\
\text { decimals }\end{array}$ & $\begin{array}{l}\text { By learning } \\
\text { preference }\end{array}$ & $\begin{array}{l}\text { Kinesthetic with base ten blocks, visual } \\
\text { with number line, and reading with } \\
\text { textbook section }\end{array}$ & $\begin{array}{l}\text { Homework } \\
\text { and Test } 1 \\
\text { Self- } \\
\text { Assessment }\end{array}$ \\
\hline 10 & Group project & $\begin{array}{l}\text { By group } \\
\text { project } \\
\text { members }\end{array}$ & $\begin{array}{l}\text { Stations based on what students needed } \\
\text { to complete their projects, e.g., peer } \\
\text { review, understanding the rubric, finding } \\
\text { resources, group work time }\end{array}$ & Quiz \\
\hline 11 & $\begin{array}{l}\text { Density of } \\
\text { numbers and } \\
\text { Test } 1\end{array}$ & $\begin{array}{l}\text { By Test } 1 \\
\text { performance }\end{array}$ & $\begin{array}{l}\text { Discuss "How close are numbers?" and } \\
\text { then differentiated activities based on } \\
\text { how students did on Test } 1\end{array}$ & Homework \\
\hline
\end{tabular}

\footnotetext{
${ }^{1}$ Students took Test 1 on Day Nine.
} 
An example of how we differentiated for readiness occurred while addressing factors and multiples during the Number Theory unit. First, the students completed an undifferentiated activity addressing definitions for factors and multiples as well as the tendency of elementary students to confuse the two terms. Then, the students completed a formative assessment. In the following class, we used a tiered activity to improve or extend the students' understandings. Students that were still refining their understandings of the terms completed an activity entitled Name that Number. For each number, students were given a series of characteristics, e.g., I am thinking of a number. It is two digits, has 24 as a factor, and its digits sum to 12 . What is my number? After completing three such questions, the students prepared their own Name that Number challenges for their peers. Students that demonstrated no confusion with the terms and an understanding of prime factorization completed a series of contextual problems dealing with common factors and multiples. After solving the problems, the students prepared a presentation for their peers, including defining the least common multiple and greatest common factor, explaining at least two ways to find each, and sharing insights about solving problems with common factors and multiples. Finally, the first group presented their Name that Number challenges to the later group, and the later group offered their presentations on common factors and multiples.

To differentiate according to student interests, we allowed choice on various activities and grouped students by common interests. For example, the students completed two projects and were allowed to choose the topic for both. On the first project, students could report on a historical numeration system, create a positional numeration system, justify the need for different sets of numbers, research the history of fractions, or select a topic of their choosing. Also on each project, students could select from a variety of final products such as a written report, poster, website, radio interview, or some other appropriate product. Throughout the semester, students were sometimes grouped by common interests. For example, we often discussed word problems for the four basic operations, during which we purposely grouped students by common personal interests. Then, we asked each group to write examples of the different types of word problems in contexts related to their common interests.

To differentiate our instruction based on students' learning profiles, we varied the instructional formats over the course of the semester, sometimes offering the same experience for all students and sometimes purposely matching the students' preferences with particular activities. We utilized a variety of kinesthetic materials (manipulatives such as pattern blocks, fraction squares, base-ten blocks, and other kinesthetic activities such as using a clothesline for ordering fractions) as well as visual representations (decimal squares, Venn diagrams, pictures, etc.). The student groupings varied nearly every day, including the use of homogeneous and heterogeneous groups along with students occasionally selecting their own groups. A combination of individual, small group, and whole class instruction was used. At times, we would allow students to select activities based on an aspect of their learning profile. For example, during one lesson on different representations for decimals, we allowed students to select different activities. Those with kinesthetic preferences illustrated decimals using the base-ten blocks, those with visual preferences used decimal squares (squares broken into tenths, hundredths, or thousandths), and those with reading preferences examined a textbook section that zoomed in on the number line. After students completed their respective 
activities, we formed new groups that consisted of at least one student from each modality, and they utilized all three representations to complete additional problems on decimals.

Formative assessments along with interest and learning style inventories were used to proactively modify instruction based on students' readiness, interests, and learning profiles. Students were assessed through homework, quizzes, tests, writing prompts, and projects. All students completed the same quizzes and tests. Homework typically consisted of core problems completed by all students and then two to three problems that were differentiated for different students. Students also completed three to four writing prompts, which asked them to respond in a two-page essay to a mathematical question. For some writing prompts, students had a choice of what prompt to answer. For some assignments, students were allowed to complete revisions and potentially earn back a percentage of missed points.

We strove to inform the students of our decisions to differentiate and why. At the beginning of the course, we had students complete an Interests and Learning Profile Line Graph and a Mathematics Line Graph to illustrate the students' differences with regard to mathematical readiness, interests, and learning profiles. A discussion followed in which we shared our intention to differentiate the course, gathered input from the students about doing so, and developed classroom norms and rules. Throughout the semester, we continued to explain our differentiation choices. For example, we explained that formative assessments were to provide information about students' learning so that we could plan future instruction accordingly. As the groups changed nearly every class period, we shared the various reasons for grouping, whether according to common interests, learning preferences, random placements, mathematical readiness, or of their choosing. When using tiered activities, we explained that students would be completing different activities based on their current understanding of a mathematical concept. We explained our intent to address different learning profiles whenever we utilized kinesthetic, visual, and auditory activities and materials. Throughout, we explained the intent of allowing students to learn in ways that best supported their readiness, interests, and preferences.

To address the research questions, the primary data source consisted of a written reflection collected at the end of the semester. To provide the context for the written reflection, students first completed a Classroom Survey, based on features of differentiated instruction as described in the literature (see Table 4). Each item was measured on a six-point scale with six indicating agreement with the maximum descriptor and one indicating agreement with the minimum descriptor. Items $1,3,6,8,11,12$, and 13 are negatively presented in that the minimum descriptor better reflects a differentiated classroom. Students then selected three items from the survey to discuss in the three-page written reflection. For each item, students described their experience with the aspect and how their experience may impact their future mathematics teaching.

I analyzed the written reflections following the qualitative procedures of Marshall and Rossman (1999). To organize the data, I scanned and saved each student's written reflection, enabling coding with HyperResearch software. Next, I used an analyst-constructed typology (Patton, 1990) whereby codes were generated for the topic of each survey item, e.g., "groups" for item \#8. For the first round of coding, I coded relevant passages according to the analystconstructed categories. If a comment related to a category, I coded it accordingly regardless of whether the student noted the item. I then continued coding with several more rounds of 
inductive analysis (Patton). Within each category, patterns emerged with regard to how the students interpreted the survey item, what they experienced in class, how it supported or constrained their learning, and whether and how they planned to incorporate similar features in their future classrooms. Throughout, I tested emergent understandings and sought alternative explanations, successively revising a summary for each category. Finally, once the themes were saturated, I prepared an overall report about the students' experiences with differentiated instruction and their plans for future instruction.

Table 4

The extreme descriptors for the 14 survey items measured on a six-point scale

\begin{tabular}{cll}
\hline Item & \multicolumn{1}{c}{ Maximum Descriptor } & \multicolumn{1}{c}{ Minimum Descriptor } \\
\hline 1 & Mastery of facts and skills are the focus & Key concepts and ideas are the focus \\
2 & Uses different instructional formats & Whole class instruction dominates \\
3 & Different learning styles are addressed & Several learning styles are taken into account \\
4 & Class time is used flexibly & Class time is inflexible \\
5 & Multiple interpretations of ideas are sought & Single interpretations of ideas are sought \\
6 & The teacher solves the problems & Students \& teacher solve problems together \\
7 & Students make interest-based learning & Student interests are untapped \\
& choices & \\
8 & Students remain in the same groups & Students work in different groups \\
9 & Assessment is used before, during, and after & Assessment occurs at the end of learning to \\
& learning to guide instruction & see "who got it" \\
10 & Students have the opportunity to revise work & Students are not allowed to revise their work \\
11 & All students complete the same work & Activities and assignments are individualized \\
12 & A single form of assessment is used & Students are assessed in multiple ways \\
13 & Grades are assigned by comparing students & Grades are based on individual growth \\
14 & Students often have choices on assignments & Students have no choices on assignments \\
\hline
\end{tabular}

\section{Results}

One hundred six students completed the written reflection; 99 of whom also turned in the classroom survey. Table 5 presents the percentage of responses for each item from the Classroom Survey as well as the number of students commenting on each item in their written reflection. In comparing the present five sections (the experimental group) with a control group (five additional sections with no differentiation), we found statistically significant differences between the mean scores of the experimental group and the control group on several items of the Classroom Survey (Chamberlin \& Powers, 2010). In each case, the treatment group's scores were consistent with characteristics of differentiated instruction, revealing that the instruction from the students' perspectives appeared to meet many of their diverse needs. The qualitative results from the written reflections are provided below in decreasing order by the number of students commenting on each item. Student quotes are given as follows: the first letter identifies the instructor, the number represents a random ordering of the students in each section, and $a$ or $b$ indicates the particular instructor's section (when an instructor taught more than one section). 
Table 5

Percentage of responses on survey items and number of students addressing within reflection

\begin{tabular}{|c|c|c|c|c|c|c|c|c|}
\hline Item & $N$ & 1 & 2 & 3 & 4 & 5 & 6 & $\begin{array}{l}\text { Number of } \\
\text { Students }\end{array}$ \\
\hline Item 1 Focus of learning & 92 & $12 \%$ & $18 \%$ & $24 \%$ & $18 \%$ & $21 \%$ & $7 \%$ & 14 \\
\hline Item 2 Instructional formats & 98 & $2 \%$ & $4 \%$ & $4 \%$ & $21 \%$ & $39 \%$ & $30 \%$ & 17 \\
\hline Item 3 Learning styles & 99 & $59 \%$ & $24 \%$ & $8 \%$ & $5 \%$ & $2 \%$ & $2 \%$ & 66 \\
\hline Item 4 Class time & 95 & $2 \%$ & $2 \%$ & $6 \%$ & $21 \%$ & $40 \%$ & $29 \%$ & 21 \\
\hline Item 5 Interpretations of ideas & 99 & $1 \%$ & $1 \%$ & $4 \%$ & $13 \%$ & $35 \%$ & $46 \%$ & 47 \\
\hline Item 6 Problem solvers & 98 & $54 \%$ & $33 \%$ & $8 \%$ & $4 \%$ & $1 \%$ & $0 \%$ & 54 \\
\hline Item 7 Interests & 99 & $0 \%$ & $0 \%$ & $9 \%$ & $27 \%$ & $42 \%$ & $22 \%$ & 25 \\
\hline Item 8 Groups & 97 & $53 \%$ & $22 \%$ & $8 \%$ & $6 \%$ & $9 \%$ & $2 \%$ & 67 \\
\hline Item 9 Timing of assessment & 97 & $2 \%$ & $7 \%$ & $13 \%$ & $23 \%$ & $32 \%$ & $23 \%$ & 5 \\
\hline Item 10 Revisions & 94 & $3 \%$ & $13 \%$ & $4 \%$ & $18 \%$ & $29 \%$ & $33 \%$ & 21 \\
\hline Item 11 Individualization & 97 & $13 \%$ & $19 \%$ & $16 \%$ & $12 \%$ & $19 \%$ & $21 \%$ & 11 \\
\hline Item 12 Assessments & 97 & $22 \%$ & $37 \%$ & $17 \%$ & $11 \%$ & $10 \%$ & $3 \%$ & 13 \\
\hline Item 13 Grades & 96 & $33 \%$ & $26 \%$ & $19 \%$ & $15 \%$ & $4 \%$ & $3 \%$ & 5 \\
\hline Item 14 Student choices & 97 & $3 \%$ & $12 \%$ & $12 \%$ & $23 \%$ & $33 \%$ & $17 \%$ & 25 \\
\hline
\end{tabular}

\section{Learning Styles}

Sixty-six students stated that different learning styles were taken into account (item \#3), 43 elaborating that kinesthetic, verbal, and auditory preferences were addressed. The students typically defined kinesthetic activities as "hands-on" or including the use of "manipulatives," such as base-ten blocks, Cuisenaire rods, pattern blocks, and physically taping fractions in numerical order on a number line. With regard to visual preferences, students described that pictures, drawings, movies, diagrams, and PowerPoint presentations were helpful. Ten students perceived the needs of visual learners to require having information written down. M15b wrote, "Because I like to work things out on paper and feel it necessary to have a visual, the use of worksheets was an important tool ... Being able to work things out on paper instead of in my head was helpful." Most students stated that the main avenue to support auditory learners was lecture: "Auditory learners could listen to the engaging lectures that revolved around each session's daily schedule" (M25b). Only five students mentioned the effectiveness of allowing auditory learners to discuss material with their peers and teacher. Table 6 summarizes the different ways students reported the learning styles were incorporated in the course, while Table 7 presents the benefits students experienced as a result.

The students stated that their experiences with different learning preferences would impact their efforts to incorporate similar features in their classrooms. In justifying their plans, 37 students acknowledged that elementary students differ in their learning preferences. Many of them explained that "not all students learn in the same way" or students are "all individuals." Most often, the students (25) described plans to differentiate their instruction to better accommodate kinesthetic, visual, and auditory learning preferences, while four students described plans to differentiate student products. 
Table 6

Students' perceptions of how learning preferences were incorporated in the course

\begin{tabular}{llc}
\hline Implementation & Example Quote & $\begin{array}{l}\text { Number of } \\
\text { Students }\end{array}$ \\
\hline $\begin{array}{l}\text { A variety of approaches } \\
\text { without matching specific } \\
\text { activities with students" } \\
\text { preferences }\end{array}$ & $\begin{array}{l}\text { "Plus some students might learn better with different } \\
\text { learning styles so it is important for a teacher to teach } \\
\text { material using different things so students can learn to the } \\
\text { best of their ability" (A25). } \\
\text { preferences with different } \\
\text { class activities }\end{array}$ & $\begin{array}{l}\text { "The groups were divided into visual learners, auditory } \\
\text { learners, and kinesthetic learners. Once divided into } \\
\text { different groups, each group worked on different }\end{array}$ \\
assignments within their group" (C14b). \\
Choices on group project \\
$\begin{array}{l}\text { "For our unit projects we could choose from a variety of } \\
\text { options. This takes us back to different learning styles, } \\
\text { you can focus one project option on a visual learner and } \\
\text { maybe another for an auditory learner, this way you can } \\
\text { give each student a more one on one approach to learning } \\
\text { even though you may have a classroom of 30" (M17a). }\end{array}$ & \\
& & \\
&
\end{tabular}

Table 7

Students' perceptions of benefits from different learning styles being addressed

\begin{tabular}{llc}
\hline Benefit & Example Quote & $\begin{array}{c}\text { Number of } \\
\text { Students }\end{array}$ \\
\hline $\begin{array}{l}\text { Able to use a preferred approach } \\
\text { for learning or demonstrating } \\
\text { mathematical knowledge }\end{array}$ & $\begin{array}{l}\text { "This separation allowed students to gain the } \\
\text { knowledge they need by using their preferred } \\
\text { method of delivery. ... the instructor allowed } \\
\text { me to learn a concept on my terms and through } \\
\text { the most efficient method for me" (A31) }\end{array}$ & \\
"I like to learn visually, but after learning from & 18 \\
$\begin{array}{l}\text { Different learning styles provided } \\
\text { different approaches for solving a } \\
\text { mathematical problem }\end{array}$ & $\begin{array}{l}\text { a peer how to solve the problem through } \\
\text { kinesthetic, I enjoyed solving the problem that }\end{array}$ & \\
$\begin{array}{l}\text { Affective benefits such as feeling } \\
\text { comfortable or interested, being }\end{array}$ & $\begin{array}{l}\text { "... I have also enjoyed math class for the first } \\
\text { time in a long time. I believe my success can be }\end{array}$ & 10 \\
$\begin{array}{l}\text { less discouraged, and realizing the } \\
\text { instructor cared about students" } \\
\text { learning }\end{array}$ & $\begin{array}{l}\text { accredited to the way the class was set up in that } \\
\text { it met each student's learning type" (M15b). }\end{array}$ & \\
\hline
\end{tabular}

Forty-three students described plans to use many different preferences over time with no plans to purposely match elementary students' learning profiles with a mode of instruction. M22b explained, "Each person's learning style is unique to them in some way or another which makes it very important for teachers to present material in a variety of ways that will allow students of all learning styles to absorb the information being presented to the best of their ability." For three of these students, this choice was related to their perception of the ability of elementary students to know their learning style. As C31a explained, "With little kids, they don't really know their learning style yet at that age, so when you use many 
different concepts of teaching to teach a classroom, the chances of kids grasping the idea are much greater than just sticking with one method of teaching." In contrast, 17 students did describe plans to match elementary students by their learning styles with corresponding activities. Five of these students explained that they would arrange this matching by allowing elementary students to select a group or activity: "I could set up different workstations that are aimed to help with different learning styles and let the kids choose which activity they would like to do" (C18a).

\section{Group Work}

Forty-seven students commented on group composition (item \#8), while an additional 20 students talked about working in groups in general. The students mentioned multiple benefits of collaborating with their peers, including the opportunity to learn from each other, to witness different approaches to mathematical problems, and to hear explanations from their peers that may resonate with them more so than explanations from the instructor.

Table 8

Students' perceptions of benefits of working in different groups

\begin{tabular}{|c|c|c|}
\hline Benefit & Example Quote & Number of Students \\
\hline $\begin{array}{l}\text { More positive classroom } \\
\text { environment and } \\
\text { community }\end{array}$ & $\begin{array}{l}\text { "I feel that this was a positive way to meet new } \\
\text { people and get a new perspective on things and } \\
\text { open up to others in the class so the whole class } \\
\text { is a positive learning environment" (C18b). }\end{array}$ & 46 \\
\hline $\begin{array}{l}\text { More comfortable } \\
\text { asking questions and } \\
\text { participating in class } \\
\text { because knew more } \\
\text { students }\end{array}$ & $\begin{array}{l}\text { "For the first time in my education career, } \\
\text { students worked in different groups at different } \\
\text { times. ... I became comfortable with the class as } \\
\text { a whole and was not afraid to ask or answer } \\
\text { questions during the time we were together" } \\
\text { (A26). }\end{array}$ & 9 \\
\hline $\begin{array}{l}\text { Helped students learn to } \\
\text { communicate, work with } \\
\text { each other, and develop } \\
\text { social skills }\end{array}$ & $\begin{array}{l}\text { "This way, it forced people to become } \\
\text { comfortable around different people and I think } \\
\text { this helped with learning not only math, but } \\
\text { social skills too" (A14). }\end{array}$ & 9 \\
\hline $\begin{array}{l}\text { Separated friends and } \\
\text { prevented the same } \\
\text { person from "always } \\
\text { doing all the work" }\end{array}$ & $\begin{array}{l}\text { "That way they are not always with their friends } \\
\text { or with people that they know will do all the } \\
\text { work for them" (C5b). }\end{array}$ & 7 \\
\hline $\begin{array}{l}\text { Kept the class more } \\
\text { interesting and fun }\end{array}$ & $\begin{array}{l}\text { "With the constant switching of tables, } \\
\text { sometimes it was a lot of fun to be able to sit } \\
\text { somewhere else instead of the same grubby chair } \\
\text { all period, facing the same direction" (M8b). }\end{array}$ & 6 \\
\hline $\begin{array}{l}\text { Encouraged acceptance } \\
\text { of diversity and reduced } \\
\text { student cliques }\end{array}$ & $\begin{array}{l}\text { "Students who work with different peers have the } \\
\text { opportunity to learn to interact with many } \\
\text { different personality types ... . This may foster } \\
\text { and encourage acceptance of diversity" } \\
\text { (C22b). }\end{array}$ & 5 \\
\hline
\end{tabular}


Forty-seven students mentioned working in different groups, acknowledging that groups were composed according to learning styles, mathematical understandings, interests, student choice, and student acquaintances (encouraging students to get to know several of their peers). Six students commented on the use of homogeneous groups, two students commented on heterogeneous groups, and five students commented on both. Students noted two advantages of homogeneous groups. First, they allow the teacher to target instruction according to students' needs:

If a group of students understood the concept being taught and needed no more additional instruction, she would give them an activity to work on that ...presented a little bit more of a challenge using the same concept. If needed, she provided additional help and/or worksheets for us to work on to help further our understanding of the concept. (A16)

Second, the students felt that homogeneous groups enhanced their ability to work together.

I would be put with people who were in the same boat as me. If I was pretty confident with the material, then I would be with other people who knew what they were doing so no one would have to carry the group. On the other hand, if I was struggling with what we were learning, I would be placed with those people so we could all work out what the problems were together and there was not that one person who was frustrated because they understood and no one else did. (C5b)

The students mentioned several benefits of working in different groups, see Table 8 . In contrast, 13 students did mention that different groups reduce the opportunity for students to build relationships and develop trust with a subset of students.

Forty-one students plan to have their elementary students work in different groups; five students plan to use homogeneous groups, three students plan to use heterogeneous groups, and five students plan to use both. Although groups were altered nearly everyday in the undergraduate class, ten students mentioned that they would only change groups with their elementary students on a weekly, monthly, or quarterly basis. A few of these students explained that they would switch less frequently in order to not "confuse" elementary students, to allow them to become comfortable with a particular group, or to lessen the trouble of moving desks. Finally, 12 students plan to have elementary students work collaboratively in groups but did not comment on altering the composition of such groups.

\section{Solving Problems}

Fifty-four students commented on who took part in solving problems (item \#6), revealing various interpretations of "the students and the teacher solve problems together" (see Table 9). While the students interpreted differently this item, there was uniformity with regard to what the teacher should not do. Thirty students wrote that the teacher should not solve the entire problem for the students or just give students the answer.

The students noted several benefits of the students and the teacher working together. First, this process helped them better understand, learn, or retain the mathematics (43 students). Second, the joint emphasis on solving problems helped them feel more comfortable in class, including asking questions and participating in discussions (11 students). Third, this process allowed students to learn from their mistakes or use "trial and error" in their learning (8 students) and to learn from their peers ( 8 students). Finally, this process allowed students to 
make progress when they were "stuck" on a problem or prevented them from being so frustrated with a problem that they "gave up" (7 students).

Most of the students plan to include the students and the teacher solving problems together in their mathematics teaching. The main difference is the tendency by nine students to qualify their plans based on perceptions of the capabilities of elementary students. Three students noted that elementary students need to be older to present their work to each other. Three other students felt that elementary students were capable themselves of problem solving but doing so might require some adaptations from that done with college students: "Although elementary students may need more help than college students, I think it's fair to assume that youngsters are more than capable of problem solving and logical thinking" (M14a). Finally, two students described teacher-directed processes that would reduce the cognitive demand and problem solving opportunities for elementary students.

Table 9

Students' interpretations of "the students and the teacher should solve problems together"

\begin{tabular}{|c|c|c|}
\hline Interpretation & Example Quote & Number of Students \\
\hline $\begin{array}{l}\text { Students had opportunities to } \\
\text { make sense of the } \\
\text { mathematics themselves }\end{array}$ & $\begin{array}{l}\text { "Through these activities, I was able to ... } \\
\text { discover the math concept for myself instead } \\
\text { of being told about it" (M24a). }\end{array}$ & 12 \\
\hline $\begin{array}{l}\text { Students worked on their } \\
\text { own and sought teacher } \\
\text { assistance when they } \\
\text { encountered difficulties }\end{array}$ & $\begin{array}{l}\text { "... our teacher would give us the } \\
\text { opportunity to try it out on our own and if we } \\
\text { were stuck, she would help us part of the } \\
\text { way and we could figure out the rest } \\
\text { ourselves" (C18b). }\end{array}$ & 12 \\
\hline $\begin{array}{l}\text { Students presented at the } \\
\text { board and the teacher } \\
\text { facilitated as needed }\end{array}$ & $\begin{array}{l}\text { "This meant that we all worked together } \\
\text { to present our work on the board and we } \\
\text { even, as students, came up to the board } \\
\text { and drew out our ideas as well as } \\
\text { explained them" (C31a). }\end{array}$ & 11 \\
\hline $\begin{array}{l}\text { Students worked on group } \\
\text { activities and then } \\
\text { participated in whole class } \\
\text { discussions }\end{array}$ & $\begin{array}{l}\text { "Our job was to work with others at our table } \\
\text { to solve the given problems. ... Once each } \\
\text { student had a fair amount of time to look } \\
\text { over and complete the worksheet, we would } \\
\text { come together as a class to discuss the } \\
\text { problems worked on" (A10). }\end{array}$ & 10 \\
\hline $\begin{array}{l}\text { When presenting at the } \\
\text { board, the teacher elicited } \\
\text { input from the students }\end{array}$ & $\begin{array}{l}\text { "[Author] never finishes a problem on her } \\
\text { own, but gets the students involved every } \\
\text { single time" (A26). }\end{array}$ & 9 \\
\hline
\end{tabular}

\section{Multiple Interpretations of Ideas}

Forty-seven students commented on multiple interpretations of ideas (item \#5), typically equating multiple interpretations with "many different ways" to solve a mathematical problem. Thirteen students explained that these multiple ways were elicited during whole class discussions, often following group work. Other students highlighted that the activities or the instructor elicited multiple approaches: "He would encourage us to figure out new ways to understand particular problems and have us use as many ways as we could. . . For 
example, just this last week we were taught multiple ways to multiply two fractions together." (M3b).

Several students (34) explained that the "different ways" supported their mathematical learning. Specific benefits are outlined in Table 10. Nearly all students (44) talked about using different methods in their future classrooms, typically explaining that if an elementary student does not understand one way, then they will present another: "I think that it is very important to learn as many ways possible to find the solution to the problem, especially when teaching to younger kids. That way if a student does not understand how to solve a problem one way, he can be taught a different way that might help him get a better grasp of the situation" (M19b). Other approaches included combinations of teaching one or two methods along with the standard algorithm. Despite these different plans, the students (22) typically shared the same purpose: By providing multiple methods, elementary students may select the method that they understand, find easier or faster, are comfortable with, or makes the most sense to them. The mathematics course also appeared to help many of the students (22) recognize that elementary students will often solve mathematical problems in unconventional ways. Due to this realization, the teachers do not intend to simply mark work incorrect if it "looks different," but rather to make sense of the elementary student's thinking to assess whether their work is mathematically logical.

Table 10

Students' perspectives of benefits of multiple interpretations of ideas

\begin{tabular}{|c|c|c|}
\hline Benefit & Example Quote & Number of Students \\
\hline $\begin{array}{l}\text { Recognizing that there } \\
\text { are many ways to solve } \\
\text { mathematical problems, } \\
\text { in contrast to the common } \\
\text { perception that there is } \\
\text { only one way }\end{array}$ & $\begin{array}{l}\text { "When I was in elementary school, I was never } \\
\text { taught any of these methods. ... Exploring } \\
\text { alternate algorithms has opened my mind to so } \\
\text { many possibilities. The idea that there is more } \\
\text { than just the standard way of doings things is } \\
\text { wonderful for teaching" (M3a). }\end{array}$ & 14 \\
\hline $\begin{array}{l}\text { Students could select the } \\
\text { method that made the } \\
\text { most sense to them or that } \\
\text { was the most efficient or } \\
\text { simple. }\end{array}$ & $\begin{array}{l}\text { "This supported my learning because I learned } \\
\text { one thing in many different ways. So let's say } \\
\text { one person in class couldn't grasp an idea one } \\
\text { way, so maybe the other method would make } \\
\text { more sense to them or just 'click' with them } \\
\text { better" (C31a). }\end{array}$ & 13 \\
\hline $\begin{array}{l}\text { The different ways helped } \\
\text { students understand the } \\
\text { standard algorithms. }\end{array}$ & $\begin{array}{l}\text { "As I looked at the other interpretations I could } \\
\text { understand why the standard algorithm actually } \\
\text { worked due to place value mainly shown by the } \\
\text { base ten blocks and [partial product] method" } \\
\text { (C15a). }\end{array}$ & 11 \\
\hline
\end{tabular}

\section{Survey Items Mentioned by a Moderate Number of Students}

Twenty-five students wrote about revising their work (item \#10). The revisions allowed them to learn from their mistakes or enhance their understanding of the mathematics. A1 explained, "I think that being able to revise missed work is a great way to clear up any confusion and reach a genuine understanding of the material." Another common benefit (13 students) was the chance to alleviate a negative effect, whether a bad grade, feeling 
discouraged, or having to complete an assessment on a "bad day." Twenty-three students plan to allow revisions with their elementary students. Seven students described limiting revisions, concerned that elementary students would not take assessments "seriously" the first time. Limitations included partial credit, limited number of revisions, retaining the original score, and not informing students about revisions ahead of time.

When students commented on choices in class (item \#14) or on student interests (item \#7), the same themes emerged. Twenty-five students commented on choices within their class, including the options available on group projects (15 students), providing input on class policies and due dates (10), selecting certain questions on assignments (6), and deciding which activities to complete in class (4). The students described many benefits of such choices (see Table 11).

Table 11

Students' perceptions of benefits of choices

\begin{tabular}{|c|c|c|}
\hline Benefit & Example Quote & $\begin{array}{l}\text { Number of } \\
\text { Students }\end{array}$ \\
\hline $\begin{array}{l}\text { Choices supported } \\
\text { students' learning }\end{array}$ & $\begin{array}{l}\text { "By making our own choices, my class and I were able to } \\
\text { learn to our full abilities" (C15a). }\end{array}$ & 11 \\
\hline $\begin{array}{l}\text { Choices allowed } \\
\text { creativity }\end{array}$ & $\begin{array}{l}\text { "It shows that a teacher can give the same assignment but } \\
\text { just gives the student the ability to get creative" (M5b). }\end{array}$ & 7 \\
\hline $\begin{array}{l}\text { Choices made } \\
\text { assignments more } \\
\text { enjoyable }\end{array}$ & $\begin{array}{l}\text { "I felt like when I was presenting the class could see } \\
\text { that the project was something that I truly enjoyed and } \\
\text { it wasn't something I just did because it was for a } \\
\text { grade" (C3a). }\end{array}$ & 7 \\
\hline $\begin{array}{l}\text { Students felt in charge of } \\
\text { their own learning }\end{array}$ & $\begin{array}{l}\text { "The ways that we got to do the assignments allowed } \\
\text { me to feel in charge of my own learning" (C20a). }\end{array}$ & 7 \\
\hline $\begin{array}{l}\text { Students were more } \\
\text { interested and motivated }\end{array}$ & $\begin{array}{l}\text { "Students are a lot more interested in a subject when they } \\
\text { get to make some decisions. ... I think that for myself and } \\
\text { others, when you get to pick an assignment you might put } \\
\text { forth more work and thought" (M11a). }\end{array}$ & 6 \\
\hline $\begin{array}{l}\text { Students could select } \\
\text { assignments for more } \\
\text { practice or to demonstrate } \\
\text { learning }\end{array}$ & $\begin{array}{l}\text { "This gave students the freedom to do problems that } \\
\text { they felt they needed more practice on" (M3b). }\end{array}$ & 3 \\
\hline
\end{tabular}

Sixteen students plan to provide similar choices for their future elementary students. However, nine students noted that providing choices may need to be adjusted for elementary students, as "younger children need more structure" (M13b), "are not ready for the responsibility to be in charge like that" (C20a), and are not "old enough at that age to make decisions" (A32).

Twenty-one students commented on class time (item \#4), as explained in Table 12. Nineteen students appreciated the class time flexibility because more time could be spent on concepts that they did not understand. In describing their future practice, seven students talked about using assessment data to adjust their class time: "Like Professor [Chelsea] I would be able to keep track of my student's progress throughout each unit, and adjust class time to issues that need to be addressed and progress on when the students were ready" (C13a). In addition, eight students will spend the time needed for elementary students to 
understand the mathematics, even if that means becoming 'off schedule'. C9a remarked, "I want their understanding to be more important than the schedule that I have planned out."

In contrast to mathematics courses typically consisting of lectures and taking notes, 17 students remarked that different instructional formats were used in class (item \#2), including activities (12 teachers), hands-on or kinesthetic activities (9), group work (8), students presenting (6), teacher explanations (5), individual activities (3), and whole class discussion (5). The students described several benefits of having multiple instructional formats, see Table 13. Eight of the students plan to use different instructional formats in their teaching, typically in ways and reasons they found helpful in class.

Table 12

Students' interpretations of flexible class time

\begin{tabular}{|c|c|c|}
\hline Interpretation & Example Quote & $\begin{array}{l}\text { Number of } \\
\text { students }\end{array}$ \\
\hline $\begin{array}{l}\text { Class time was used } \\
\text { flexibly according to } \\
\text { students' mathematical } \\
\text { understandings }\end{array}$ & $\begin{array}{l}\text { "If the class did not understand a concept or the class } \\
\text { felt like we did not have enough time to work on } \\
\text { something, then the professor had no problem with } \\
\text { spending more time" (C17a). }\end{array}$ & 19 \\
\hline $\begin{array}{l}\text { Instructor knew how to } \\
\text { adjust class time due to } \\
\text { assessments }\end{array}$ & $\begin{array}{l}\text { "By testing the students during the instruction, the } \\
\text { instructor was able to gather feedback on how well the } \\
\text { students' understandings of the concepts were coming } \\
\text { along. This allows the teacher to modify the curriculum } \\
\text { as it is in practice by adding or subtracting key } \\
\text { information" (A31). }\end{array}$ & 7 \\
\hline $\begin{array}{l}\text { Instructor used student } \\
\text { input in adjusting class } \\
\text { time }\end{array}$ & $\begin{array}{l}\text { "In a classroom that works the time is divided on how } \\
\text { the students think is important. We usually take a class } \\
\text { vote on what the students think should be done during } \\
\text { class time" (A7). }\end{array}$ & 5 \\
\hline
\end{tabular}

Table 13

Students' perceptions of benefits of multiple instructional formats

\begin{tabular}{|c|c|c|}
\hline Benefit & Example Quote & $\begin{array}{l}\text { Number of } \\
\text { Students }\end{array}$ \\
\hline $\begin{array}{l}\text { Most of the formats } \\
\text { actively engaged students } \\
\text { in exploring the } \\
\text { mathematics }\end{array}$ & $\begin{array}{l}\text { "Being able to do these kinds of activities also helps } \\
\text { to keep our attention better and be able to be hands } \\
\text { on with learning, instead of always just sitting and } \\
\text { listening and having to take notes. Doing these kinds } \\
\text { of assignments helps you to better comprehend the } \\
\text { material" (C4a). }\end{array}$ & 12 \\
\hline $\begin{array}{l}\text { Many formats included } \\
\text { collaborative work with } \\
\text { peers }\end{array}$ & $\begin{array}{l}\text { "These different instructional formats ... worked } \\
\text { well because we received instruction from another } \\
\text { peer and how they perceived the information, } \\
\text { then relating it to our own work" (C14b). }\end{array}$ & 8 \\
\hline $\begin{array}{l}\text { Formats allowed students to } \\
\text { make sense of the material } \\
\text { on their own }\end{array}$ & $\begin{array}{l}\text { "Through these activities, I was able to ... } \\
\text { discover the math concept for myself instead of } \\
\text { being told about it" (M24a). }\end{array}$ & 7 \\
\hline
\end{tabular}




\section{Less Frequently Discussed Survey Items}

Fourteen students commented on the focus of learning (item \#1), saying that the emphasis was to understand mathematics (how and why it works) rather than to memorize facts or determine the right answer. Thirteen students mentioned that this emphasis enhanced their understanding. C16b remarked, "I am a horrible math student and this was the first course to tell me why I was doing math and many different ways to do certain problems that make more sense to me." As C16b explained, fourteen students stated that they feel more confident and better prepared to teach mathematics. Six students stated that they want their instruction to emphasize understanding rather than just memorization or rules and procedures: "This did a lot to impact my future teaching. This showed me just how important it is for students to learn concepts behind the answers" (M11b). Two students noted adjustments they would make to this approach for elementary students: "Their brains can't grasp these concepts yet. ... I see the facts and skills as the foundation children need when they first start learning math" (M23b).

Thirteen students commented that a variety of assessments were used (item \#12), with three benefits. First, multiple assessments provide a variety of formats that may better align with students' learning preferences or interests ( 7 students), offering more and better opportunities for students to demonstrate their learning. Second, multiple assessments provide numerous affective benefits, including alleviating test anxiety, increasing confidence and interest, and communicating that the teacher cares about student learning (9 students). Finally, varied assessments provide multiple opportunities for students to engage with the material (4 students). Nine students will use multiple assessments in their future teaching, mirroring their experiences in the undergraduate class with a few exceptions. Two students plan to rely more on weekly quizzes than large exams; another student plans to use observation rather than student questioning; and one student plans to not give take-home tests.

Eleven students stated that activities were individualized for students based on their understandings (item \#11). A31 explained, "Upon issuing assessments and gathering data, the instructor was able to create individualized activities." Six students noted that individualization was facilitated through homogeneous groups when different groups completed different activities based on their readiness. Seven students commented that individualization supported their learning: "It was very helpful that [Author] took time to individualize our assignments to provide better understanding for a concept" (A16). Eight students explained that such individualization allowed students to receive more help or to move on to another topic as needed: "By having extra problems, that really gave me a chance to practice. I think this supported everyone's learning in this classroom because maybe they got a subject more than others did, well that meant they could move on to different things to study" (A3). In considering their future teaching, all 11 students plan to use different activities and assignments for elementary students.

Five students stated that grading was based on individual growth rather than on comparing students (item \#13). Four students were glad to be graded individually because students learn at different rates. C27a explained, "Everyone has different ways and speeds of learning. ... I know that I don't learn as fast as other students and sometimes it's harder for me to understand something the first time it is told to me, so I appreciate the way that professor 
[Chelsea] grades each student on their individual knowledge rather than the classes knowledge as a whole." Another benefit was that such grading reveals the growth of an individual's understanding over time. Finally, three students mentioned that they do plan to grade elementary students on their individual growth: "When I become a teacher, ... I won't grade a student based off of what another student knows" (C27a).

Finally, five students commented that assessments were used before, during, and after learning to guide instruction (item \#9), and all plan to do so similarly in their instruction. Three students commented that with this continuous assessment, the instructors were able to appropriately adjust class time throughout instruction. Two other students found such assessments helpful for providing feedback on their learning. C3a stated, "Assessments before, during, and after class had finished helped to see the progress the student had made throughout the class, and showed different struggles the student had with certain concepts."

\section{Discussion}

The first purpose of implementing differentiated instruction in our mathematics course was to meet the diverse learning needs of our college students. From the Classroom Survey and the written reflections, it appears that the course did meet many of the students' instructional needs. They reported the course actively engaged them in making sense of the mathematics, met their different learning profiles, incorporated a variety of instructional formats, adjusted to their mathematical understandings, allowed input on their learning, offered multiple formats for demonstrating their learning, and provided individualized assignments. Hopefully such experiences were counter to the typical structure of undergraduate mathematics classes being impersonal, irrelevant, and intellectually unstimulating (Anthony, 2000; Gainen, 1995; Treisman, 1992; Willis; 1993). At a minimum, the course incorporated many instructional formats beyond lecture and emphasized active learning. As such, the course appears to have met the recommendation of Daempfle (20032004), who stated following an analysis of the literature on undergraduate attrition from science, mathematics, and engineering majors, that:

Undergraduate science, mathematics, and engineering instruction should shift from simple knowledge transmission to actively and cooperatively engaging students. Active student involvement in lectures, structuring assessment practices to include cooperative learning strategies, and increasing faculty involvement would improve student attitudes, achievement, and retention. (p. 48)

The students' positive reports of differentiated instruction in this class illustrate the potential of differentiated instruction at the undergraduate level for meeting the diverse instructional needs and preferences of college students. Further research is needed to investigate this potential in additional undergraduate mathematics classes as well as with other undergraduate majors. Perhaps differentiated instruction would be perceived differently by non-education majors or may necessitate an altered approach.

The second purpose of this study was to examine how prospective teachers perceived the use of differentiated instruction and potential impacts on their classroom practice. Overall, the students reported an experience that supported their learning by incorporating many differentiation principles and features; features that many of the students hope to incorporate 
in their future instruction. Furthermore, the students appeared to enhance their perceptions and plans for differentiated instruction beyond the shortcomings reported by Tomlinson et al. (1994). First, they described pedagogical plans to accommodate student differences by being proactive in their instruction, contrary to the reactive tendencies of most prospective teachers (Chamberlin \& Chamberlin, 2010). Second, the majority of the students reported that this class supported them in seeing mathematics as a sense-making domain in which the teacher serves as a facilitator of students' learning, a realization that some of the students reported experiencing for the first time. This realization is crucial for understanding the justification and need for differentiated instruction. While such advances are promising, the students' comments did reveal additional aspects about differentiated instruction for them to learn or strengthen.

The frequency with which the students mentioned various differentiation principles may provide information about the likelihood of them incorporating such strategies in their teaching. Many of the prospective teachers appreciated the need to adjust instruction according to students' readiness; however, not many of them talked about incorporating student interests. Addressing kinesthetic, visual, and auditory preferences were also frequently described by the students, but other factors of learning profiles were not mentioned, e.g., learning styles or cultural background. Finally, the students less frequently mentioned revisions and choices, flexible class time, varying instructional formats, and the focus of learning, and they only rarely addressed multiple assessments, individualized assignments, and individual grading.

Another alarming tendency was that some of the students planned to adjust differentiation strategies based on their perceptions of the abilities and maturity of elementary students. Qualifying their differentiation plans due to a perception of elementary students' abilities, development, and maturity is a new result to emerge from providing prospective teachers with differentiated experiences and then asking them to consider impacts on their future practice. Attention needs to be given to helping prospective teachers critically consider how their experiences in the course may need to be adapted for elementary students, as some important adjustments likely exist. However, the adjustments described by the students in this study dilute the differentiation attempts and reduce the opportunity for sense making on the part of elementary students.

In future offerings of the course, we believe it would be helpful to include more articulation with students about the differentiation, with particular attention to proactive steps, attempts to individualize, and use of assessments. We also think it would be prudent to further differentiate with regard to learning profile, such as incorporating one or two learning style inventories (Coffield, Moseley, Hall, \& Ecclestone, 2004) and culturally responsive teaching (Bennett, 2004; DeJaeghere \& Zhang, 2008). Finally, we feel it would be helpful to address the question of how differentiation strategies might be adapted for use with elementary students without diluting the differentiation or cognitive demand.

Further research is needed to build upon these findings with prospective teachers. First, it would be helpful to refine differentiation in content courses as described above. Would teachers further enhance their plans to differentiate? What other areas might emerge that should be addressed in content courses? Furthermore, it is necessary to follow teachers through their student teaching experiences and beyond to specifically investigate how 
experiences in their program, whether in content courses or perhaps through later educational coursework and field experiences, may impact their abilities to address learner variance. While modeling pedagogy in a mathematics content course may have limitations for impacting teachers' actual practice, it serves as a place to start. By experiencing differentiated instruction in a mathematics content course, prospective teachers have the opportunity to begin enhancing their future mathematics teaching while also having their own diverse instructional needs met.

\section{References}

Anthony, G. (2000). Factors influencing first-year students' success in mathematics. International Journal of Mathematical Education in Science and Technology, 31(1), 3-14. doi: $10.1080 / 002073900287336$

Batts, K., \& Lewis, S. G. (2005). How to implement differentiated instruction? Journal of Staff Development, 26(4), 26-31.

Bennett, M. J. (2004). Becoming interculturally competent. In J. Wurzel (Ed.), Toward multiculturalism: A reader in multicultural education ( $2^{\text {nd }}$ ed., pp. 62-77). Newton, MA: Intercultural Resource Corporation.

Brighton, C. M., Hertberg, H. L., Moon, T. R., Tomlinson, C. A., \& Callahan, C. M. (2005). The feasibility of high-end learning in a diverse middle school (RM05210). Storrs, CT: The National Research Center on the Gifted and Talented, University of Connecticut.

Brimijoin, K. (2002). Expertise in differentiation: A preservice and inservice teacher make their way. Unpublished doctoral dissertation, University of Virginia, Charlottesville, VA.

Business-Higher Education Forum. (2005). A commitment to America's future: Responding to the crisis in mathematics and science education. Hagerstown, MD: Author.

Cavanagh, S. (2004). Students ill-prepared for college, ACT warns. Education Week, 24(8), 5-5.

Chamberlin, M. T., \& Chamberlin, S. A. (2010). Administering a series of problem solving tasks to upper grade elementary gifted students: What elementary pre-service teachers learned. Journal for the Education of the Gifted, 33, 233-268.

Chamberlin, M. T., \& Powers, R. A. (2010). The promise of differentiated instruction for enhancing the mathematical understandings of college students. Teaching Mathematics and Its Applications: An International Journal of The Institute of Mathematics and Its Applications, 29(3), 113-139. doi:10.1093/teamat/hrq006

Coffield, F., Moseley, D., Hall, E., \& Ecclestone, K. (2004). Learning styles and pedagogy in post-16 learning: A systematic and critical review. London, Learning and Skills Research Centre. Retrieved October 24, 2011 from http://www.hull.ac.uk/php/edskas/learning\% 20styles.pdf.

Daempfle, P. A. (2003-2004). An analysis of the high attrition rates among first year college science, math, and engineering majors. Journal of College Student Retention, 5(1), 37-52. doi:10.2190/DWQT-TYA4-T20W-RCWH

DeJaeghere, J. G., \& Zhang, Y. (2008). Development of intercultural competence among US American teachers: Professional development factors that enhance competence. Intercultural Education, 19(3), 255-268. doi: 10.1080/14675980802078624 
Gainen, J. (1995). Barriers to success in quantitative gatekeeper courses. New Directions for Teaching and Learning, 61, 5-14. doi:10.1002/t1.37219956104

Gould, H. C. (2004, December). Can novice teachers differentiate instruction? Yes, they can! In New Horizons for Learning. Retrieved August 30, 2010, from http://www.newhorizons.org/strategies/differentiated/gould.htm

Hodge, P. H. (1997). An analysis of the impact of a prescribed staff development program in differentiated instruction on student achievement and the attitudes of teachers and parents toward that instruction. Unpublished Ed.D. thesis. University of Alabama, USA.

Horn, L., \& Nevill, S. (2006). Profile of undergraduates in U.S. postsecondary education institutions: 2003-04: With a special analysis of community college students (NCES 2006-184). U.S. Department of Education. Washington, DC: National Center for Education Statistics.

Huss-Keeler, R., \& Brown, S. (2007). Meeting diverse learning needs: Differentiating instruction in graduate early childhood mathematics classes. Journal of Early Childhood Teacher Education, 28(1), 41-57. doi:10.1080/10901020601184390

Marshall, C., \& Rossman, G. (1999). Designing qualitative research. Thousand Oaks, CA: Sage.

McAdamis, S. (2001). Teachers tailor their instruction to meet a variety of student needs. Journal of Staff Development, 22(2), 1-5.

Patton, M. Q. (1990). Qualitative evaluation \& research methods. Thousand Oaks, CA: Sage.

Sands, D. I., \& Barker, H. B. (2004). Organized chaos: Modeling differentiated instruction for preservice teachers. Teaching \& Learning, 19(1), 26-49.

Seymour, E. (1992). Undergraduate problems with teaching and advising in SME majors explaining gender differences in attrition rates. Journal of College Science Teaching, 21, 284-298.

Subban, P. (2006). Differentiated instruction: A research basis. International Education Journal, 7(7), 935-947.

Tomlinson, C. A. (1999). The differentiated classroom: Responding to the needs of all learners. Alexandria, VA: Association for Supervision and Curriculum Development [ASCD].

Tomlinson, C. A. (2005). Traveling the road to differentiation in staff development. Journal of Staff Development, 26(4), 8-12.

Tomlinson, C. A., Brighton, C., Hertberg, H., Callahan, C. M., Moon, T. R., Brimijoin, K., . . . Reynolds, T. (2003). Differentiating instruction in response to student readiness, interest, and learning profile in academically diverse classrooms: A review of literature. Journal for the Education of the Gifted, 27(2/3), 119-145.

Tomlinson, C. A., \& Eidson, C. C. (2003). Differentiation in practice: A resource guide for differentiating curriculum grades $K-5$. Alexandria, VA: ASCD.

Tomlinson, C. A., \& McTighe, J. (2006). Integrating differentiated instruction and understanding by design. Alexandria, VA: ASCD.

Tomlinson, C. A., Tomchin, E. M., Callahan, C. M., Adams, C. M., Pizzat-Tinnin, P., Cunningham, C. M., . . . Imbeau, M. (1994). Practices of preservice teachers related to gifted and other academically diverse learners. Gifted Child Quarterly, 38(3), 106-114. doi: $10.1177 / 001698629403800303$ 
Treisman, U. (1992). Studying students studying calculus: A look at the lives of minority mathematics students in college. The College Mathematics Journal, 23(5), 362-372. doi: $10.2307 / 2686410$

Wertheim, C., \& Leyser, Y. (2002). Efficacy beliefs, background variables, and differentiated instruction of Israeli prospective teachers. Journal of Educational Research, 96(1), 54-63. doi: $10.1080 / 00220670209598791$

Willis, D. (1993). Academic involvement at university. Higher Education, 25, 133-150. doi:10.1007/BF01384745

\section{Author}

Michelle T. Chamberlin, Assistant Professor of Mathematics Education, University of Wyoming, Department of Mathematics \#3036, 1000 E. University Ave., Laramie, WY, 82071, USA; mchambe5@uwyo.edu. 